\title{
Nutritional profile of sugar-sweetened beverages destined to the youngsters marketed in Brazil and Portugal
}

\author{
Perfil nutricional de bebidas açucaradas \\ destinadas ao público infantojuvenil \\ comercializadas no Brasil e em Portugal
}

Nathalia Nunes Lopes SCRAFIDE ${ }^{1}$ (iD) 0000-0001-8433-4152

Aline de PIANO GANEN1 1 (D) 0000-0001-6433-0816

\section{A B S T R A C T}

\section{Objective}

To analyze and compare the sugar content in sugar sweetened beverages in Brazil and Portugal, according to the Pan American Health Organization nutritional profile model.

\section{Methods}

One hundred six equivalent sugary beverages were selected in the markets of São Paulo, Brazil and Porto, Portugal. Nutritional information reported on the labels was reviewed, according to the Pan American Health Organization nutritional profile model, regarding the critical content of free sugars, salt, total saturated fats and trans fatty acids.

\section{Results}

The Brazilian nectars presented higher amounts of sugar and vitamin C compared to Portuguese nectars that contained more protein. The juices in Portugal contained a higher content of vitamin $\mathrm{C}$ and Portuguese dairy beverages had higher levels of protein and sodium, while the Brazilian ones had more total fats. According to the critical nutrients proposed by the Pan American Health Organization, Brazil had excess sodium in dairy beverages and soft drinks, while in Portugal excess sodium was found in nectars and dairy beverages. In both countries, excess free sugars were present in all beverages.

\footnotetext{
1 Centro Universitário São Camilo, Departamento de Nutrição, Programa de Mestrado Profissional em Nutrição: do Nascimento à Adolescência. R. Raul Pompéia, 144, Pompéia, 05025-010, São Paulo, SP, Brasil. Correspondence to: A PIANO GANEN. E-mail: <aline.depiano@gmail.com>.

Article based on the dissertation of NNL SCRAFIDE, entitled "Avaliação e comparação do teor de açúcar em bebidas prontas para o consumo destinadas ao público infanto-juvenil comercializadas no Brasil e em Portugal”. Centro Universitário São Camilo; 2019.
}

How to cite this article

Scrafide NNL, Piano Ganen A. Nutritional profile of sugar-sweetened beverages destined to the youngsters marketed in Brazil and Portugal. Rev Nutr. 2020;33:e190116. http://dx.doi.org/10.1590/1678-9865202033e190116 


\section{Conclusion}

The amount of sugar in the beverages represents an important contribution of added sugar, especially in the Brazilian nectars. The identification of this component in sugary beverages is fundamental for the adoption of strategies of food education to control obesity.

Keywords: Carbonated beverages. Child nutrition. Fruit and vegetable juices. Obesity.

\section{RE S U M O}

\section{Objetivo}

Este estudo buscou analisar e comparar o teor de açúcar presente em bebidas prontas para consumo no Brasil e em Portugal, segundo o modelo de perfil nutricional da Organização Pan-Americana de Saúde.

\section{Métodos}

Selecionaram-se 106 bebidas açucaradas comercializadas nos mercados das cidades de São Paulo e do Porto. Analisaram-se informações nutricionais nos rótulos, conforme o modelo de perfil nutricional da Organização Pan-Americana de Saúde, quanto ao teor crítico de açúcares livres, sal, gorduras totais, saturados e ácidos graxos trans.

\section{Resultados}

Os néctares brasileiros apresentaram maior quantidade de açúcar e vitamina C; os portugueses evidenciaram maior valor proteico. Os sucos em Portugal continham maior teor de vitamina C, e as bebidas lácteas portuguesas demonstraram ter maior teor de proteína e sódio; já as brasileiras, maior quantidade de gorduras totais. De acordo com os nutrientes críticos propostos pela Organização Pan-Americana de Saúde, o Brasil possuiu excesso de sódio nas bebidas lácteas e refrigerantes, enquanto Portugal, nos néctares e nas bebidas lácteas. Em ambos os países, o excesso de açúcares livres esteve presente em todas as bebidas.

\section{Conclusão}

A quantidade de açúcar nas bebidas representa uma expressiva contribuição de açúcar adicionado, destacandose os néctares brasileiros. A identificação desse componente em bebidas açucaradas é fundamental para a adoção de estratégias de educação alimentar contra a obesidade.

Palavras-chaves: Bebidas gaseificadas. Nutrição da criança. Suco de frutas e vegetais. Obesidade.

\section{NTRODUCTION}

Childhood obesity includes complex interactions of multiple non-modifiable and modifiable factors. A modifiable factor is food choice, which may include high consumption of sugary drinks that is considered one of the main factors that led to the obesity epidemic [1].

The latest National Health Survey showed that 32.3\% of children under two years of age consume soda frequently [2]. The Study of Cardiovascular Risks in Adolescents (ERICA) revealed that $44.97 \%$ of Brazilian adolescents aged 12 to 17 years regularly consume soda, and this is the sixth most consumed food [3].

In 2017, the Agência Nacional de Saúde (National Health Agency), in Rio de Janeiro, during the Regional Meeting to Control Childhood Obesity, established goals to reduce the growth of overweight and obesity rates in the country, among them, to reduce the regular consumption of soft drinks and artificial juice in at least 30\% in the adult population, by 2019 [4]. Likewise, the Food Guide for the Brazilian Population warns about the risks of excessive consumption of ultra-processed foods, such as sugary drinks [5].

Some countries have taken fiscal measures to protect people from unhealthy products [6]. Portugal started taxing in February 2017. In 2015, the World Health Organization (WHO) had already 
issued a first alert on sugar consumption, which generated a strong reaction from the private sector and sugar exporters around the world $[7,8]$. In Brazil, producers' organizations even participated in the consultations and, in light of the findings, rebutted the WHO proposals, warning that it is not only the consumption of sugar that has contributed to this trend, but also sedentary life and other foods [6].

In addition, in 2014, the Pan American Health Organization (PAHO) prepared a manual on the nutritional profile of foods for the development of standards and regulations for non-alcoholic drinks and foods with high energy density and low nutritional value [9].

It is emphasized that the best understanding of factors associated with the consumption of sugar-sweetened drinks in children, as well as identifying their nutritional profile, can support the development of interventions to promote healthy nutrition and prevent childhood obesity [10]. Thus, the present study aims to review and to compare the sugar content present in ready-to-drink nonalcoholic beverages according to the legislation in force in Brazil and in Portugal, following the PAHO nutritional profile model [11].

\section{METHODS}

This is a descriptive cross-sectional study that investigated the amount of sugar and other nutritional components contained in ready-to-drink beverages and evaluated the current legislation on children's beverages marketed in Brazil and Portugal. The collection of nutritional information on the packaging labels for ready-to-drink beverages was carried out in the months of January and February 2018 in the city of São Paulo, Brazil and in the city of Porto, Portugal.

A survey was conducted on the website of the Brazilian Supermarket Association, where the three largest supermarkets in the city of São Paulo were identified, according to the variety of products, chain, sales and best prices. On the other hand, in Portugal, according to a study carried out by the Portuguese Association for Consumer Protection in 2017, the two largest markets in the city of Porto were selected, using the same selection criteria applied for the markets in the city of São Paulo.

Pictures of the nutritional tables of all available products were collected during the investigation period; products were equivalent in both countries such as fruit juices, fruit nectars, soft drinks and milk drinks, from where the following information was retrieved: 200 milliliters portion, brand, kilocalories, total fat in grams (g), saturated fat in grams $(\mathrm{g})$, total carbohydrates in grams (g), sugars in grams (g), protein in grams (g), fiber in grams (g), sodium in milligrams (mg) and vitamin C in grams (g).

Powder juices, coconut water, teas, soy-based drinks and diet and light drinks were excluded from the sample. Powdered juices were excluded because they are not ready-to-drink, as they require water for their reconstitution. Coconut water is not commonly marketed in Portugal and was thus excluded from the sample. Teas, as they do not have a commercial appeal for children, were also excluded. Diet drinks contain sweeteners, not being eligible for the study in question, as well as light drinks that have $25 \%$ less sugar in $200 \mathrm{~mL}$ portion.

The drinks were categorized into 4 groups: juices, nectars, soft drinks and milk drinks. This division was based on the national legislation of both countries regarding the characterization of beverages, where juice is considered a non-fermented, non-concentrated and undiluted drink, intended for direct consumption, obtained from healthy and ripe fruit, or part of the original plant, by an appropriate technological process, submitted to a treatment that ensures its presentation and 
conservation until consumption. The nectar has less pure juice content [12-14]. Soda is characterized as carbonated drink, obtained by dissolving carbon dioxide in drinking water, and juice or original plant extract, added with sugar [15]. Finally, milk products are obtained from milk or reconstituted milk and/or milk derivatives, reconstituted or not, fermented or not, with or without the addition of other ingredients [16].

\section{Assessment according to the criteria used in the PAHO Nutritional Profile Model}

In order to assess the amount of sugar in soft drinks, we considered the PAHO recommendation which classifies the drink with an excess of free sugars, if in a certain amount of the product, the amount of energy (kcal) from free sugars (grams of free sugars) $\times 4 \mathrm{kcal}$ ) is equal to $10 \%$ or more of the total energy value (kcal) [11]. In addition, the Model also includes the amount of critical nutrients, such as sodium, sweeteners, total, saturated and trans fats.

Excess sodium was considered when the ratio between the amount of sodium in the product and the energy value was $\geq 1: 1$. Products with excess of total and saturated fats were considered those drinks that had an amount of $\geq 30 \%$ and $\geq 10 \%$ of the total energy value of the product, respectively.

\section{Statistical Analysis}

The analyses were performed based on the $200 \mathrm{~mL}$ portion of the sugar-sweetened drinks ready for consumption. The variables' normality test was performed using the Kolmogov-Smirnov test and it was found that energy (Kcal), total carbohydrates and sugars showed normal distribution, while the other variables were considered non-parametric. Thus, the Student's $t$ test was applied to compare the components of sugary drinks in Brazil and Portugal for the parametric variables and the Mann Whitney test was used for the non-parametric variables. Statistical analysis was performed using the software Statistica version 6.0 for Windows, considering the significance level of $p<0.05$.

\section{R E S U L T S}

A total of 106 sugar-sweetened drinks, marketed in the city of São Paulo, Brazil, and in the city of Porto, Portugal were selected, distributed in 35 brands available (21 brands in São Paulo and 14 brands in the city of Porto). In Brazil, the amount of total sugar present in nectars averaged $22 \mathrm{~g}, 18.5 \mathrm{~g}$ in juices, $19 \mathrm{~g}$ in soft drinks and $23.4 \mathrm{~g}$ in dairy drinks per $200 \mathrm{~mL}$ portion. In Portugal, in comparison, the average total sugar found was $17.9 \mathrm{~g}$ in nectars, $22.3 \mathrm{~g}$ in juices, $20.8 \mathrm{~g}$ in soft drinks and $22.1 \mathrm{~g}$ in dairy drinks per $200 \mathrm{~mL}$ portion.

It was observed that sugary drinks (nectar) sold in Brazil contained a higher amount of sugar and vitamin C, while in Portugal they had higher protein content (Table 1). When comparing the juices marketed in Brazil and Portugal, it was noted that in Portugal they contained a greater amount of vitamin C (Table 2).

According to the nutritional composition of sugary drinks marketed in Brazil and Portugal, dairy drinks in Brazil contained a larger amount of total fats, while in Portugal they had a higher protein and sodium content (Table 3). Verifying the results obtained in Table 4, it was found that there was no statistical difference between the nutritional components of soft drinks analyzed in both countries. 
Table 1. Nutritional composition of nectars marketed in Brazil and Portugal, 2018.

\begin{tabular}{|c|c|c|c|}
\hline \multirow{2}{*}{ Nutritional Components } & Brazil & Portugal & \multirow{2}{*}{$p$ value } \\
\hline & $\mathrm{M} \pm \mathrm{SD}$ & $\mathrm{M} \pm \mathrm{SD}$ & \\
\hline Calories (Kcal) & $88.66 \pm 26.99$ & $82 \pm 17.09$ & 0.296 \\
\hline Total Fat $(\mathrm{g})^{*}$ & $0(0-0)$ & $0(0-0.20)$ & 0.090 \\
\hline Saturated Fat $(\mathrm{g})^{*}$ & $0(0-0)$ & $0(0-0)$ & 0.390 \\
\hline Total Carbohydrates (g) & $22.06 \pm 7.08$ & $19.87 \pm 4.27$ & 0.186 \\
\hline Sugars (g) & $22.03 \pm 7.14$ & $17.88 \pm 4.07$ & 0.013 \\
\hline Protein $(\mathrm{g})^{*}$ & $0(0-0)$ & $0.20(0-0.40)$ & 0.026 \\
\hline Sodium $(\mathrm{mg})^{*}$ & $0(0-7.4)$ & $0(0-0)$ & 0.430 \\
\hline Fibers $(\mathrm{g})^{*}$ & $0(0-0)$ & $0(0-0)$ & 0.903 \\
\hline Vitamin C $(m g)^{*}$ & $20(14-27)$ & $0(0-12)$ & 0.000 \\
\hline
\end{tabular}

Note: *Values expressed in median IQR (25-75).

M: Mean; SD: Standard Deviation; IQR: Interquartile Range.

Table 2. Nutritional composition of nectars marketed in Brazil and Portugal, 2018.

\begin{tabular}{|c|c|c|c|}
\hline \multirow{2}{*}{ Nutritional Components } & Brazil & Portugal & \multirow{2}{*}{$p$ value } \\
\hline & $\mathrm{M} \pm \mathrm{SD}$ & $\mathrm{M} \pm \mathrm{SD}$ & \\
\hline Calories (Kcal) & $85.25 \pm 21.69$ & $92 \pm 8.09$ & 0.464 \\
\hline Total Fat $(\mathrm{g})^{*}$ & $0(0-0.05)$ & $0(0-0)$ & 0.350 \\
\hline Saturated Fat $(\mathrm{g})^{*}$ & $0(0-0)$ & $0(0-0)$ & 1.000 \\
\hline Total Carbohydrates (g) & $20.16 \pm 5.42$ & $22.33 \pm 2.50$ & 0.353 \\
\hline Sugars (g) & $18.54 \pm 4.55$ & $22.33 \pm 2.50$ & 0.060 \\
\hline Protein $(\mathrm{g})^{*}$ & $0(0-0)$ & $0(0-0)$ & 0.436 \\
\hline Sodium $(\mathrm{mg})^{*}$ & $3.25(0-10)$ & $5(5-10)$ & 0.400 \\
\hline Fibers $(g)^{*}$ & $0(0-1.2)$ & $0(0-0)$ & 0.276 \\
\hline Vitamin C $(\mathrm{mg})^{*}$ & $14(0-37.5)$ & $30(30-60)$ & 0.043 \\
\hline
\end{tabular}

Note: *Values expressed in median IQR (25-75).

M: Mean; SD: Standard Deviation; IQR: Interquartile Range.

Table 3. Nutritional composition of dairy drinks marketed in Brazil and Portugal, 2018.

\begin{tabular}{|c|c|c|c|}
\hline \multirow{2}{*}{ Nutritional Components } & Brazil & Portugal & \multirow{2}{*}{$p$ value } \\
\hline & $\mathrm{M} \pm \mathrm{SD}$ & $\mathrm{M} \pm \mathrm{SD}$ & \\
\hline Calories (Kcal) & $152.5 \pm 20.86$ & $135.42 \pm 21.93$ & 0.146 \\
\hline Total Fat $(\mathrm{g})^{*}$ & $3.35(3-4.35)$ & $2.40(2.2-3)$ & 0.007 \\
\hline Saturated Fat $(\mathrm{g})^{*}$ & $1.95(1.9-2.25)$ & $1.60(1.4-20)$ & 0.090 \\
\hline Total Carbohydrates (g) & $25.50 \pm 4.75$ & $21.23 \pm 4.33$ & 0.093 \\
\hline Sugars (g) & $23.38 \pm 5.76$ & $21.11 \pm 4.30$ & 0.410 \\
\hline Protein $(\mathrm{g})^{*}$ & $4(3.75-4.65)$ & $6.60(6.2-7)$ & 0.001 \\
\hline Sodium $(\mathrm{mg})^{*}$ & $174(130.5-194)$ & $260(240-320)$ & 0.001 \\
\hline Fibers $(\mathrm{g})^{*}$ & $0(0-1.15)$ & $0.60(0-1)$ & 0.816 \\
\hline Vitamin $C(m g)^{*}$ & $3.40(0-8.6)$ & $0(0-0)$ & 0.105 \\
\hline
\end{tabular}

Note: *Values expressed in median IQR (25-75).

M: Mean; SD: Standard Deviation; IQR: Interquartile Range.

When assessing the critical nutrients proposed by the PAHO Nutritional Profile Model contained in sugary drinks, we can see that in Brazil there is an excess sodium in milk and soft drinks, reaching $62.5 \%$ and $20 \%$ respectively in the products analyzed. While in Portugal $3.6 \%$ of nectars and $100 \%$ of milk drinks had a higher frequency of excess sodium. In both countries there was excess of free sugars in all drinks assessed and the excess of saturated fats was more frequent in dairy drinks both in Brazil (75\%) and in Portugal (71.4\%) (data not reported in the table). 
Table 4. Nutritional composition of soft drinks marketed in Brazil and Portugal, 2018.

\begin{tabular}{|c|c|c|c|}
\hline \multirow{2}{*}{ Nutritional Components } & Brazil & Portugal & \multirow{2}{*}{$p$ value } \\
\hline & $\mathrm{M} \pm \mathrm{SD}$ & $\mathrm{M} \pm \mathrm{SD}$ & \\
\hline Calories (Kcal) & $77.2 \pm 11.48$ & $84.29 \pm 11.10$ & 0.307 \\
\hline Total Fat $(\mathrm{g})^{*}$ & $0(0-0)$ & $0(0-0)$ & 1.000 \\
\hline Saturated Fat $(\mathrm{g})^{*}$ & $0(0-0)$ & $0(0-0)$ & 1.000 \\
\hline Total Carbohydrates (g) & $19.0 \pm 2.92$ & $20.94 \pm 2.74$ & 0.266 \\
\hline Sugars (g) & $19.0 \pm 2.92$ & $20.8 \pm 2.68$ & 0.294 \\
\hline Protein $(g)^{*}$ & $0(0-0)$ & $0(0-0)$ & 1.000 \\
\hline Sodium $(\mathrm{mg})^{*}$ & $11(10-12)$ & $0(0-40)$ & 0.370 \\
\hline Fibers $(g)^{*}$ & $0(0-0)$ & $0(0-0.20)$ & 0.416 \\
\hline Vitamin C $(\mathrm{mg})^{*}$ & $0(0-0)$ & $0(0-0)$ & 0.569 \\
\hline
\end{tabular}

Note: *Values expressed in median IQR (25-75).

M: Mean; SD: Standard Deviation; IQR: Interquartile Range.

\section{DISCUSSION}

The present study can be considered of great relevance and of an unprecedented character, since it evaluated the quantity, the percentage of sugar contribution and the nutritional profile of sugary drinks marketed in two countries, using the PAHO Nutritional Profile Model. To the best of our knowledge, there are no studies reported in the literature that performed this type of review, providing information for reflection on their contribution to the intake of unhealthy foods, which are highly consumed by children.

As already mentioned, the WHO claims that high sugar consumption among children and adolescents, mainly in sugary drinks, is one of the main factors for the increase in obesity rates and comorbidities in this population [6]. Our results showed that the nectars selected in Brazil contained a higher amount of sugar when compared to those of Portugal, and soft drinks were considered as the highest sugar contributors in both countries, as pointed by PAHO standards [11].

The difference between juice and nectar are associated with the content of fruit juice contained in the drink. The nectar has a lower content of pure juice, containing at least 20 to $30 \%$ juice, depending on the degree of acidity of the fruit. This category may also contain sweeteners, dyes, preservatives and additives, which are generally cheaper than the soluble solids of fruits, which are the main cause of flavor, that is, they are added with other substances that have the same function and are cheaper [17].

The average sugar content found in nectars was $22 \mathrm{~g}$ per $200 \mathrm{~mL}$ in Brazil and $18 \mathrm{~g}$ in Portugal, similar to the amount observed in a study carried out in the United Kingdom, where the content of sugar available in juices, nectars and smoothies in $200 \mathrm{~mL}$ portions only intended for youngsters was analyzed. Out of the 158 nectars analyzed, 85 contained at least $19 \mathrm{~g}$ of sugars in $200 \mathrm{~mL}$ - the maximum recommended daily intake of free sugars [17].

It is suggested that, as in Brazil the amount of fruit pulp contained in the nectar goes up to $30 \%$, with no national parameter on the amount of sugar added to the nectars in the legislation, the addition of sugar by the manufacturers becomes arbitrary, and may exceed the recommended dose. This could explain why the average sugar content in Brazil is higher, since in Portugal the legislation allows manufacturers to add a maximum of $20 \%$ sugar to the nectars and use a minimum of $25 \%$ juice of fruits with high acidity and $50 \%$ of fruits with a good taste $[14,15]$. 
In a project carried out by Sonneville et al. [18] juice intake before 1 year of age was associated with a higher intake of juices and sugary drinks during early and middle childhood and also with greater adiposity.

Fisberg et al. [19] evaluated the average consumption of sugary drinks by children aged 4 to 11 years in the different meals of the day, considering the contribution of each drink in the intake of added sugar. The authors pointed out that the early start of consumption of these drinks and their presence in most meals are worrisome, since their glycemic index is high, associating them with insulin resistance, which may culminate in non-alcoholic liver disease, diabetes and metabolic syndrome.

In a national study conducted with adolescents from a public school, it was found that the most consumed drink during meals was processed fruit juice (38\%), followed by soft drinks (29\%). The authors warn about the potential deleterious effects of those drinks, because in addition to contributing to the increase in energy density through the supply of empty calories, their consumption does not favor the activation of the satiety center, since they are in liquid form [20].

The consumption of sugary drinks by children and adolescents should be restricted, while the consumption of water and other unsweetened drinks should be encouraged. Educational institutions, such as day care centers, preschools and schools, must offer unlimited access to drinking water, while the sale of sugar-sweetened drinks should be prohibited [21].

Although in our investigation the consumption of these beverages by the population was not evaluated, which can be considered a limitation, our data allows us to identify that 29 beverages reach a content of $100 \%$ of the recommended maximum daily intake of free sugars according to the WHO in just a $200 \mathrm{~mL}$ portion [22].

Governments play a facilitating role in providing settings that are prepared to tackle no communicable diseases, but the evidence on the effectiveness of increasing state involvement using fiscal measures to change population's consumption of less sugary drinks is still limited. It is acknowledged that no single action can offer a solution to effectively reduce sugar intake and the consumption of sugary drinks. A wide range of strategies may be needed to positively affect choices at individual, community and national levels [23]. The identification and the nutritional analysis of the sugar content of sugary drinks, according to the criteria and critical values established by national and international guidelines, can be considered an extremely relevant action, as it can warn about their nutritional quality. The inclusion of front-of-pack nutritional labels highlighting the sugar content is one of the strategies proposed to encourage healthy food selection and is considered a measure of greater support and effectiveness by the population [24,25].

Price policies, such as the implementation of taxation measures for certain foods, motivated by reasons of public health can be effective in reducing the impact of diseases caused by their excessive consumption [26]. According to some estimates obtained from meta-analyses carried out in the past $[23,27]$, a decrease of $76 \mathrm{~mL}$ of sugary drinks by children could represent a reduction of about one-third of a $240 \mathrm{~mL}$ portion size (equivalent to 2.5 teaspoons of sugar or $20 \%$ of energy intake from free sugars) potentially reducing risk factors for tooth decay, type II diabetes and obesity.

Although the school stands out as one of the most common channels to steer behaviors to reduce obesity (including reduction of sweetened drinks), it was found that home is the most effective setting for reducing the consumption of sugary drinks [28]. Corroborating this statement, in a survey on the consumption of sugary drinks among adolescents, it was found that, when they were asked about the place of greatest consumption of soft drinks, $38 \%$ pointed out "at home" and $22 \%$ 
"at school", indicating the need to change this habit in the family context [20]. The need to evaluate behavioral change initiatives to decrease the intake of free sugars and, in particular, sugar-sweetened drinks has been emphasized as a health research gap [23].

In the present study, the average quantity of sugar found in dairy drinks in Brazil and Portugal was $23.4 \mathrm{~g}$ and $22.1 \mathrm{~g}$, per portion respectively, with no statistical difference. In a study carried out in Poland, it was observed that milk drinks for children had a higher sugar content when compared to products for the adult population, where $75 \%$ of the products were sweetened, with 6.9 to $12.3 \mathrm{~g}$ of sugar in $100 \mathrm{~mL}[29]$.

In Portugal, dairy drinks were high in protein and sodium. We can attribute this high protein content compared to Brazil to the Portuguese legislation that requires manufacturers to produce this type of drink with at least $71 \%$ milk base while the Brazilian legislation only requires $51 \%$. On the other hand, the higher sodium content is due to the fact that the drink contains food additives in its formulation, where this type of substance introduced in the drink considerably increases the quantity of sodium in the product [16].

In Brazil, Agência Nacional de Vigilância Sanitária (National Agency for Health Surveillance) issued a Technical Regulation on Flavoring Additives listing the additives that are allowed in food [30]. Portugal follows Regulation (EU) n.1129/2011 of the European Union on food additives that are substances intentionally added to foods to increase the durability of the product, or to enhance or modify its organoleptic properties [31]. In the production process of milk drinks, which are widely consumed by children and adolescents, large amounts of additives are added, among them sodium citrate, used as a stabilizer. No legislation has been found that controls or determines a standard quantity for these products that consequently raise the sodium quantities.

In Portugal, $100 \%$ of the dairy drinks contained excess sodium. Analyzing the ingredients of those drinks, it is verified that, in almost all dairy drinks, refined salt is present, in addition to food additives such as stabilizers and thickeners that contain sodium in their composition. In Brazil, $62.5 \%$ of dairy drinks had excess sodium in their composition (sodium chloride, thickeners and stabilizers).

Sodium is a nutrient that enhances fluid retention by the body, causing an increase in blood volume, and, therefore, the risk of arterial hypertension. Excessive consumption in childhood can increase the chances of developing this disease, especially if there is a family history. Its high consumption can also reduce bone mineral density by stimulating urinary calcium excretion [32].

In the present study, there was no statistical difference between all the nutritional components of soft drinks between the two countries; however it is known that this kind of drink has high sugar concentrations. The average sugar found in soft drinks was $19 \mathrm{~g}$ in Brazil and $20.8 \mathrm{~g}$ per portion in Portugal. Portuguese preschoolers who consumed sugary drinks daily were 1.52 times more likely to develop overweight or obesity when compared to preschoolers who did not consume these drinks regularly [33].

Myszkowska-Ryciak and Harton have shown that kindergarten education has great potential to improve the variety of drinks served in preschools. With the educational intervention, the percentage of Polish preschools serving water during and between meals (67\% and $83 \%$ to $93 \%$ and $99 \%$, respectively) and natural fruit juices (46\% to $56 \%$ ) increased significantly. The percentage of preschools offering soft drinks decreased from $23 \%$ to $15 \%$ after the intervention [34]. A study carried out in Poland and Belgium shows that there is a higher consumption of soft drinks and 
less water consumption in these two countries [35]. Other studies confirm the tendency to replace soft drinks with other drinks with a better nutritional profile, such as milk and natural juices in children and in the adolescent population $[36,37]$, indicating the need to implement specific policies to improve nutritional habits in those populations.

In addition, it was found that soft drinks marketed in our country had excess sodium, exceeding the critical level established by the PAHO nutritional profile model. Most soft drinks in Brazil have preservatives and stabilizers in their composition such as acidulant phosphoric acid, caramel dye IV, citric acid, sodium benzoate and potassium sorbate, sodium citrate that end up contributing to increasing sodium in such beverages.

According to the PAHO Nutritional Profile Model, during the past decades, several international organizations have advocated healthy nutrition and reduction of calories, sodium, unhealthy fats and free sugars consumption. This caused some countries to issue rules, regulations and policies related to food. These strategies included taxing sugary drinks, improving school nutrition, regulating advertising and promoting children's food and front-of-pack nutrition label [11].

The taxation proposal in Portugal was created and approved in view of the global appeal of the WHO to reduce childhood obesity. It is extremely important to have public policies in place to make the population aware of the need to reduce sugar consumption, especially of sugary drinks [38].

In our study, no evaluation of the consumption of these drinks by the population was performed, which did not allow us to explore the possible association with socio-economic factors in food selection, nor did it allow us to identify the impact on consumption of the taxation of some of these drinks in Portugal. However, we can infer that a significant number of the sugary drinks analyzed can contribute to reaching and even exceeding the recommendation of maximum daily sugar intake, according to $\mathrm{WHO}$, in the pediatric population, showing which categories have the highest content of sugar and of critical nutrients.

\section{CONCLUSION}

The amount of sugar in beverages represents an expressive percentage contribution of added sugar, highlighting the Brazilian nectars. It is noteworthy the high content of free sugar contained in the dairy beverages of both countries. The Identification and comparison of components in sugarsweetened drinks are essential for the adoption of food education strategies against obesity, and help encouraging a discussion about the implementation of other measures, such as fiscal instruments as an effective approach to promote healthy nutrition.

\section{CONTRIBUTORS}

A PIANO GANEN and NNL SCRAFIDE contributed to the conception and design, analysis and interpretation of data, review and approval of the final version of the article.

\section{A C KNOWLEDGMENTS}

We thank the Institutional support given by Centro Universitário São Camilo. 


\section{REFERE N CES}

1. Sanghavi A, Siddiqui NJ. Advancing oral health policy and advocacy to prevent childhood obesity and reduce children's consumption of sugar-sweetened beverages. J Public Health Dent. 2017;77:88-95. http://dx.doi. org/10.1111/jphd.12235

2. Ministério da Saúde (Brasil). Pesquisa Nacional de Saúde: PNS 2013. Brasília: Ministério da Saúde, 2013 [citado 2019 maio 10]. Disponível em: http://svs.aids.gov.br/dantps/acesso-a-informacao/inqueritosdesaude/ pns/2013/

3. Bloch KV, Cardoso MA, Sichieri R. Study of Cardiovascular Risk Factors in Adolescents (ERICA): results and potentiality. Rev Saúde Públ. 2016;50(1):1-3. http://dx.doi.org/10.1590/s01518-8787.201605000supl1ap

4. Agência Nacional de Saúde Suplementar (Brasil). Manual de diretrizes para o enfrentamento da obesidade na saúde suplementar brasileira: PNDS 2017. Rio de Janeiro: Agência; 2017 [citado 2019 maio 12]. Disponível em: http://www.ans.gov.br/images/final_obesidade_26_12.pdf

5. Ministério da Saúde (Brasil). Guia alimentar para a população brasileira. 2 ed. Brasília: Ministério; 2014.

6. World Health Organization. Report of the commission on ending childhood obesity Geneva: World; 2016 [cited 2019 May 7]. Available from: http://apps.who.int/iris/bitstream/10665/204176/1/9789241510066_ eng.pdf?ua=1

7. Briggs ADM, Mytton OT, Kehlbacher A, Tiffin R, Elhussein A, Rayner M, et al. Health impact assessment of the UK soft drinks industry levy: a comparative risk assessment modelling study. Lancet Public Health. 2017;2(1):2-3. http://dx. doi.org/10.1016/s2468-2667(16)30037-8

8. Lopes R. Avaliação do impacto da taxação das bebidas açucaradas no consumo de bebidas em geral [tese]. Porto: Universidade do Porto; 2017.

9. Organização Pan-Americana de Saúde. Plano de ação para prevenção da obesidade em crianças e adolescentes. Washington: Organização; 2014 [citado 2019 abr. 28]. Disponível em: https://www.paho.org/ bra/images/stories/UTFGCV/planofactionchildobesity-por.pdf?ua=1

10. Jaime PC, Prado RR, Malta DC. Family influence on the consumption of sugary drinks by children under two years old. Rev Saúde Pública. 2017;51(1):1-10. http://dx.doi.org/10.1590/s1518-8787.2017051000038

11. Organização Pan-Americana de Saúde. Modelo de perfil nutricional da Organização Pan-Americana de Saúde. Washington: Organização; 2016 [citado 2019 maio 10]. Disponível em: https://iris.paho.org/ bitstream/handle/10665.2/18623/9789275718735_por.pdf?sequence=9\&isAllowed=y

12. Ministério da Agricultura, Pecuária e Abastecimento (Brasil). Instrução Normativa $n^{\circ} 12$, de 4 de setembro de 2003. Aprova o regulamento técnico para fixação dos padrões de identidade e qualidade gerais para suco tropical; os padrões de identidade e qualidade dos sucos tropicais de abacaxi, acerola, cajá, caju, goiaba, graviola, mamão, manga, mangaba, maracujá e pitanga; e os padrões de identidade e qualidade dos néctares de abacaxi, acerola, cajá, caju, goiaba, graviola, mamão, manga, maracujá, pêssego e pitanga. Brasília: Ministério; 2003 [citado 2019 abr. 30]. Disponível em: http://www.agricultura.gov.br/assuntos/ inspecao/produtos-vegetal/legislacao-1/biblioteca-de-normas-vinhos-e-bebidas/instrucao-normativa-no-12de-4-de-setembro-de-2003.pdf/view

13. Longo-Silva G, Toloni MHA, Menezes RCE, Asakura L, Oliveira MAA, Taddei JAAC. Introdução de refrigerantes e sucos industrializados na dieta de lactentes que frequentam creches públicas. Rev Paul Pediatr. 2015;33(1):34-41.

14. Ministério da Agricultura, Desenvolvimento Rural e Pescas (Portugal). Decreto-Lei n²25/2003, de 24 de setembro. Definições e características dos sumos de frutos e dos produtos similares e às regras que devem reger a sua rotulagem. Porto: Ministério; 2003 [citado 2019 abr. 28]. Disponível em: https://dre.pt/ application/conteudo/494050

15. Ministério da Agricultura, Pecuária e Abastecimento (Brasil). Decreto federal n6.871, de 4 de junho de 2009. Regulamenta a Lei $n^{\circ}$ 8.918, de 14 de julho de 1994, que dispões sobre a padronização, a classificação, o registro, a inspeção, a produção e a fiscalização de bebidas. Brasília: Ministério; 2009 [citado 2019 abr. 29]. Disponível em: http://www.agricultura.gov.br/assuntos/vigilancia-agropecuaria/ivegetal/bebidasarquivos/ decreto-no-6-871-de-4-de-junho-de-2009.doc/view

16. Ministério da Agricultura, Pecuária e Abastecimento (Brasil). Instrução Normativa n³6, de 31 de outubro de 2000. Regulamento técnico de identidade e qualidade de bebidas lácteas. Brasília: Ministério; 2000 [citado 
2019 maio 2]. Disponível em: http://www.lex.com.br/doc_19408_INSTRUCAO_NORMATIVA_N_36_DE_31_ DE_OUTUBRO_DE_2000.aspx.

17. Boulton J, Hashem KM, Jenner KH, Lloyd-Williams F, Bromley H, Capewell S. How much sugar is hidden in drinks marketed to children? A survey of fruit juices, juice drinks and smoothies. BMJ Open. 2016;6(3):e010330. http://dx.doi.org/10.1136/bmjopen-2015-010330

18. Sonneville KR, Long MW, Rifas-Shiman SL, Kleinman K, Gillman MW, Taveras EM. Juice and water intake in infancy and later beverage intake and adiposity: could juice be a gateway drink? Obesity. 2015;23(1):170-6. http://dx.doi.org/10.1002/oby.20927

19. Fisberg M, TascaDel'Arco APW, Previdelli AN, Almeida CAN. Consumo de bebidas por crianças brasileiras com idades entre 4 e 11 anos de idade e seu impacto na ingestão de açúcar de adição: estudo de amostragem nacional. Int J Nutr. 2016;9(2):169-81.

20. Estima CCP, Philippi ST, Araki EL, Leal GVS, Martinez MF, Alvarenga MS. Consumo de bebidas e refrigerantes por adolescentes de uma escola pública. Rev Paul Pediatr. 2011;29(1):41-5.

21. Deren K, Weghuber D, Caroli M, Koletzko B, Thivel D, Frelut ML, et al. Consumption of sugar-sweetened beverages in paediatric age: a position paper of the european academy of pediatrics and the european childhood obesity group. Ann Nutr Metab. 2019;74(4):296-302. http://dx. doi.org/10.1159/000499828

22. Organização Mundial da Saúde. Diretriz: ingestão de açúcares por adultos e crianças. Genebra: Organização; 2015.

23. Vargas-Garcia EJ, Evans CEL, Prestwich A, Sykes-Muskett BJ, Hooson J, Cade JE. Interventions to reduce consumption of sugar-sweetened beverages or increase water intake: evidence from a systematic review and meta-analysis. Obes Rev. 2017;18(11):1350-63. http://dx.doi.org/10.1111/obr.12580

24. Lima M, Ares G, Deliza R. How do front of pack nutrition labels affect healthfulness perception of foods targeted at children? Insights from Brazilian children and parents. Food Qual Prefer. 2018;64:111-9. http:// dx.doi.org/10.1016/j.foodqual.2017.10.003

25. Billich N, Blake MR, Backholer K, Cobcroft M, Li V, Peeters A. The effect of sugar-sweetened beverage front-of-pack labels on drink selection, health knowledge and awareness: an online randomized controlled trial. Appetite. 2018;128:224-33. http://dx.doi.org/10.1016/j.appet.2018.05.149

26. Goiana-da-Silva F, Nunes AM, Miraldo M, Bento A, Breda J, Araújo FF. Using pricing policies to promote public health: the sugar sweetened beverages taxation experience in Portugal. Acta Med Port. 2018;31(4):191-5. http://dx.doi.org/10.20344/amp.10222

27. Rees K, Dyakova M, Ward K, Thorogood M, Brunner E. Dietary advice for reducing cardiovascular risk (review). Cochrane Database Syst Rev. 2013;28:1-159. http://dx.doi.org/10.1002/14651858.cd002128.pub4

28. Vézina-Im LA, Beaulieu D, Bélanger-Gravel A, Boucher D, Sirois C, Dugas M, et al. Efficacy of school-based interventions aimed at decreasing sugar-sweetened beverage consumption among adolescents: a systematic review. Public Health Nutr. 2017;20(13):2416-31. http://dx.doi.org/10.1017/s1368980017000076

29. Wirzejska R, Siuba-Strzelinska M, Jarosz M. Evaluation of dairy products available on the Polish market in the context of nutrient profiles: clear arguments for reformulation of foodstuffs. Rocz Panstw Zakl Hig. 2017;68(1):43-50

30. Agência Nacional de Vigilância Sanitária. Resolução RDC n² 2, de 15 de janeiro de 2007. Aprova o regulamento técnico sobre aditivos aromatizantes, que consta como Anexo da presente resolução. Brasília: Agência; 2007 [citado 2019 maio 7]. Disponível em: http://portal.anvisa.gov.br/documents/33916/391619/ Anexo\%2BRDC\%2B2.pdf/84947fce-1b8f-4a2c-978e-2e23cf67f1a3

31. Comissão Europeia. Regulamento (UE) n¹129/2011 da Comissão de 11 de novembro de 2011. Altera o anexo II do Regulamento (CE) n¹333/2008 do Parlamento Europeu e do Conselho mediante o estabelecimento de uma lista da União de aditivos alimentares); 2011 [citado 2019 maio 6]. Disponível em: https://eur-lex. europa.eu/LexUriServ/LexUriServ.do?uri=OJ:L:2011:295:0001:0177:PT:PDF

32. Teixeira GLSB, Farias DMA, Macário YC, Silva NA, Vieira RS, Nascimento JS. Teores de sódio, açúcares e lipídeos de alimentos infantis comercializados no município de Caruaru-PE. Rev Eletr Estácio Recife. 2015 [citado 2019 maio 4];1(1):1-10. Disponível em: https://reer.emnuvens.com.br/reer/article/view/3/2

33. Machado-Rodrigues AM, Fernandes RA. Overweight risk and food habits in Portuguese preschool children. J Epidemiol Glob Health. 2018;8(3-4):106-9. 
34. Myszkowska-Ryciak J, Harton A. Eating healthy, growing healthy: impact of a multi-strategy nutrition education on the assortments of beverages served in preschools, Poland. Int J Environ Res Public Health. 2018;15(7):1355-65. http://dx.doi.org/10.3390/ijerph15071355

35. Craemer M, Lateva M, lotova V, Decker E, Verloigne M, Bourdeaudheij I, et al. Differences in energy balancerelated behaviours in european preschool children: the ToyBox-Study. Plos One. 2015;10(3):1-18. http:// dx.doi.org/10. 1371/journal.pone.0118303

36. Nielsen SJ, Popkin BM. Changes in beverage intake between 1977 and 2001. Am J Prev Med. 2004;27(3):205-10. http://dx.doi.org/10.1016/j.amepre.2004.05.005

37. Keller KL, Kirzner J, Pietrobelli A, St-Onge MP, Faith MS. Increased sweetened beverage intake is associated with reduced milk and calcium intake in 3- to 7-year-old children at multi-item laboratory lunches. J Am Diet Assoc. 2009;109(3):497-501.

38. Bascuñán J, Cuadrado C. Effectiveness of sugar-sweetened beverages taxes to reduce obesity: evidence brief for policy. Medwave. 2017;17(8):e7054. http://dx.doi.org/10.5867/medwave.2017.08.7054 